\title{
RESEARCH NOTE \\ The population of earthworms Lumbricus spp. on the plateau of La Paz, Bolivia
}

\author{
Manuel G. Loza-Murguía ${ }^{1}{ }^{2}$, René Acho², Alcides Arce ${ }^{2}$, Roxana Huaycho², \\ Nicanor Aruhiza ${ }^{2}$, and Sofía Mamani ${ }^{2}$ \\ ${ }^{1}$ Modulo Microbiología Ambiental. Departamento de Enseñanza e Investigación en Bioquímica \& \\ Microbiología. Unidad Académica Campesina Carmen Pampa. Universidad Católica Boliviana "San Pablo". \\ Coroico - Nor Yungas - La Paz, Bolivia. \\ ${ }^{2}$ Ingeniería Agronómica. Universidad Pública y Autónoma de El Alto (UPEA). Villa Esperanza Avenida \\ Sucre s/n Primer piso, Bloque A. Ciudad de El Alto. La Paz, Bolivia.
}

\begin{abstract}
M.G. Loza-Murguía, R. Acho, A. Arce, R. Huaycho, N. Aruhiza, and S. Mamani. 2011. The population of earthworms Lumbricus spp. on the plateau of La Paz, Bolivia. Cien. Inv.Agr. 38(3): 415-423. The macrofauna is an important component of ecosystems because its participation in the biodegradation of soil nutrients has beneficial effects on the food chain. During six months, from February through July, a number of worms and their biomass $\left(\mathrm{g} \mathrm{m}^{-2}\right)$ were assessed in the soil of the Estación Experimental of Kallutaca, located on the plateau of La Paz. A study area of one hectare of fallow land was delimited. The study area had been without tillage activity for approximately ten years. This area was divided into five rings. Each ring had eight sampling points. Each sampling point included a square meter of soil and had a depth of $30-35 \mathrm{~cm}$. The density and biomass of earthworms recorded in this study were $13.6 \pm 29.74 \mathrm{~m}^{-2}$ and $4.7315 \pm 2.3544 \mathrm{~g} \mathrm{~m}^{-2}$, respectively. The average length of the earthworms was $4.7960 \pm$ $0.6219 \mathrm{~cm}$. The environmental characteristics of the study area may influence the development of these earthworms.
\end{abstract}

Key words: Earthworms, seasonal density, soil, study area.

\section{Introduction}

Certain management practices promote ecological instability and threaten the sustainability of agroecosystems because technological developments have caused serious imbalances (Lee and Pankhurst, 1992). This problem has caused the creation of subsidy systems requiring the constant use of measures that cause negative impacts, such

Received February 2, 2010. Accepted September 18, 2011. Corresponding author: boliviamaloza@yahoo.com as salinization and soil erosion, water contamination, recurring plague breakthroughs and decreased biodiversity (Altieri, 1992; Lavelle, 2000).

The activity of the edaphic system is of great scientific interest in relation to management, use and conservation measures. Soil is a complex system resulting from the interaction of different elements. The edaphic fauna, specifically earthworms, is especially important (Edwards and Bohlen, 1996; Lavelle and Spain, 2001). The influence of earth- 
worms on soil properties, particularly their role in improving cultivated lands, has been known since ancient times. Much of the fertility of the lands of the Nile Valley was the result of the activity of these animals, which were considered "lesser Gods" in the time of Cleopatra. Aristotle defined worms as "the intestines of the Earth". In 1881, Darwin offered a scientific explanation of their true role in the ecosystem. He viewed them as authentic biological plows (Lee, 1985; Brown et al., 2003).

Earthworms are macroscopic oligochaeta, clitellate annelids living in the soil. These invertebrates represent the largest animal biomass in most temperate terrestrial ecosystems. They significantly influence the physical, chemical and biological properties of the soil. In addition, they play a crucial role in modifying the soil structure, in accelerating the decomposition of organic matter and in nutrient recycling (Edwards and Bohlen 1996; Lavelle and Spain 2001; Domínguez et al., 2004). Over 8,000 earthworm species have been described. Most of these species are known only by their names and morphology and their biology and ecology is still unknown. The different earthworm species have different life strategies and occupy different ecological niches. They have been classified in three ecological categories on the basis of their food and the zone where they live: epigeal, anecic and endogenous (Bouche, 1977).

The excreta of earthworms contain large amounts of bacteria, organic matter, nitrogen compounds and available nutrients, which are highly favorable for plant growth (De Vleeschauwer and Lal, 1981). Generally, the effect of worms on the medium takes three forms: (i) the biological stimulation of microbial populations and their activity (Daniel and Anderson, 1992; Parthasarathi and Ranganathan, 1999); (ii) the chemical enhancement of the availability of organic and mineral matter through decomposition (Norgrove and Hauser, 2000; Tiunov and Scheu, 2000); and (iii) the physical enhancement of ventilation and mineral movement between the soil horizons through aggregation (Haynes and Fraser, 1998; Shuster et al., 2000; Willoughby and Kladivko, 2002).

According to Wallwork (1970), the abundance and diversity of the edaphic mesofauna in forest ecosystems are high. According to Beare et al. (1995), Butcher and Snider (1971), Lavelle et al. (1995) and Seasted (1984), the edaphic mesofauna is important in the processes of decomposition and mineralization of organic matter and it influences the levels of fertility and therefore affects terrestrial ecosystems (Witkamp, 1971).

The distribution of worms within the soil profile is determined by abiotic factors (such as humidity and temperature) and biotic factors (the animals' behavior) (Martin and Lavelle, 1992). The vertical distribution of worms has been studied less frequently in tropical ecosystems than in temperate latitudes. Investigations of the vertical distribution of worms in the tropics include studies by Reddy and Pasha (1993) of semiarid pastures in India; by Senapati (1980) in potreros under grazing and without grazing in India; by Németh and Herrera (1982) in acid soils in a humid tropical rainforest in Venezuela; by Lavelle (1978) in different types of savanna in Lamto (Ivory Coast); and by Fragoso (1993) in natural and altered ecosystems in southeastern Mexico. In tropical ecosystems with strong seasonality, worms migrate to the lower layers of the soil to begin estivation states, such as quiescence or diapause (Fragoso, 1985, 1993, Jiménez et al., 1998, Lavelle 1978).

Lumbricus terrestris is a large-bodied species that lives in deep soil and that builds permanent vertical galleries. It feeds primarily on organic matter at the surface (De Vleeschauwer and Lal, 1981). This species is also considered an important facilitator of the decomposition of harvest residues and residual fertilizers at the surface. Its activity is related to the dynamics of soil nutrients (Binet and Trehen, 1992).

Living organisms in the plateau soils are limited for many reasons. These limiting factors include 
scarce organic matter, low temperature, precipitation, salinity, overgrazing, mechanization and natural enemies. Such factors tend to have negative effects that reduce edaphic populations.

This study focused on Lumbricus spp. because these species dominate the biomass of various ecosystems and affect the stabilization of organic matter in the soil. Information on the presence, behavior and activity of these earthworms in the soil of the area studied in this paper is scarce. The presence of varying climatic conditions in the area, whose average temperature is $13{ }^{\circ} \mathrm{C}$, implies that an evaluation of the fluctuations of earthworms (Lumbricus spp.) at the Estación Experimental of Kallutaca would provide information for the technicians, farmers and professionals of the area. No research on this topic has previously been conducted in this Andean region.

\section{Materials and methods}

\section{Study site}

This study was conducted on the Bolivian plateau near Lake Titicaca. The experimental area is located on relatively flat terrain within the lands of the Facultad of Ingeniería Agronomía, and Medicina Veterinaria of the Universidad Pública y Autónoma in El Alto (UPEA), Kallutaca (16³0’ S, $68^{\circ} 18^{\prime} \mathrm{W}$ ). The area's annual average temperature ranges from 8 to $11^{\circ} \mathrm{C}$. The study site is located $40 \mathrm{~km}$ from La Paz and $15 \mathrm{~km}$ from Lake Titicaca at 3,850 masl. The annual mean rainfall is 400 $\mathrm{mm}$ and $80 \%$ of the rainfall occurs during the crop season (November through April). Frosts may occur at almost any time during the year (Camacho, 2001). The soil type is clay silt to clay. The study was made in a hectare of soil in fallow land (approximately 10 years old).

\section{Soil material}

Samples were collected weekly from February through July 2009. On sampling days, two samples were collected, one at 5 am and one at $7 \mathrm{am}$.

A central point was identified (point zero) and eight radial lines were defined from that point. Five sampling rings were marked on each radial line to the peripheral limit of the sampling area. The rings were spaced every $10 \mathrm{~m}$ (Figure 1). A total of 40 sampling points were defined in a total surface area of one hectare. A Garmin eTrex H Global Positioning System (GPS) was used to identify the locations of the rings and the sampling points. Samples were collected at each point by digging to a depth of $0.35 \mathrm{~m}$ in a $1 \times 1 \times 0.30 \mathrm{~m}$ plot. Linear measurements were made with a fiberglass XD-Metal tape measure. A 40-cm deep ditch 15 to $20 \mathrm{~cm}$ wide was made to prevent the worms from escaping through the sides of the study plot.

The sample was initiated in the upper left quadrant of the study plot and continued clockwise ring by ring. Each ring received a code (A1, A2, A3, A4 and A5), where (A) designates the ring and 1, 2, 3, 4 and 5 are the numbers that were used to identify the rings. The designation MAN2009 was used to identify the method.

All weeds were removed from each sampling point. The surface was subsequently marked at each point. Each point represented $1 \mathrm{~m}^{2}$ of surface (Figure 1).

\section{Biological material}

The sampling points were first defined in the experimental area. At each sampling point, the entire soil sample was then poured onto a 1.5 x $1.5 \mathrm{~m}$ white polyethylene sheet to count the number of worms (Lumbricus spp.). The point was identified with a small colored flag. A red flag indicated that the colony was large (10 or more individuals), a yellow flag indicated that the colony was medium sized (from 5 to 10 individuals), and a green flag indicated that the population was small (5 individuals or fewer). The worms 
obtained from the samples were placed in white polyethylene bags and transported immediately to the soils laboratory for evaluation.

In the laboratory, the individuals were placed in $250-\mathrm{cm}^{3}$ beakers containing an $0.9 \%$ sodium chloride solution. The worms were subsequently separated and identified using an Olympus CH30 stereo-microscope. They were weighed on a 0.001-g precision AND scale after being washed and dried by exposure to the environment for 15 minutes. The length of each worm $(\mathrm{cm})$ was measured with a Faber Castell triangle scale (153B) and the population density was measured in worms $\mathrm{m}^{-2}$. The biomass was expressed in $\mathrm{g} \mathrm{m}^{-2}$.

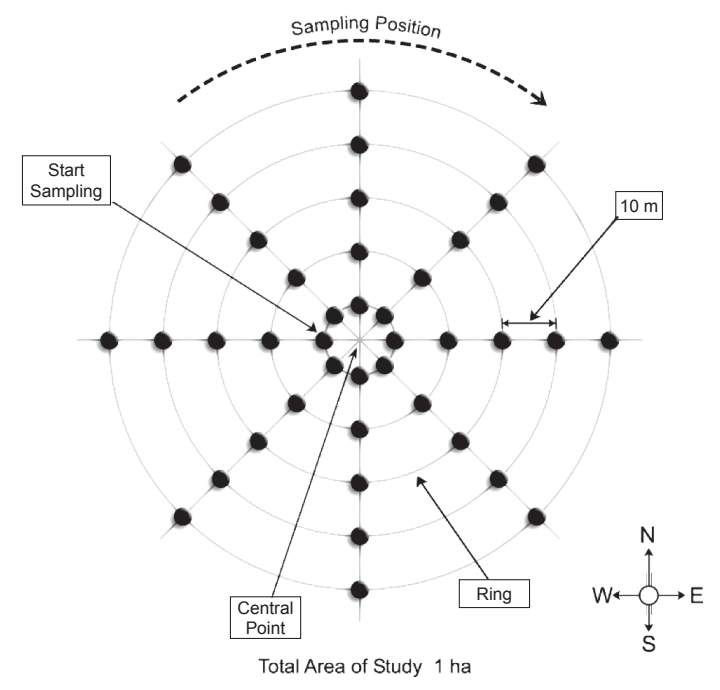

Figure 1. Sampling design for the study area Designation MAN2009.

\section{Results}

Number and density of worms

In all, 544 worms were recorded in the five rings evaluated. The numbers of worms per ring decreased from 144 worms in A1 to 68 worms in A5. The population density for the study area calculated from these values was $13.6 \pm 29.74$ worms $\mathrm{m}^{-2}$ (Table 1).

\section{Biomass of worms}

The biomass varied among sampling points. The lowest biomass, $2.0201 \mathrm{~g} \mathrm{~m}^{-2}$, was recorded at sampling point 8 . The highest value, recorded at point 3, was $9.6225 \mathrm{~g} \mathrm{~m}^{-2}$ (Table 2).

The average biomass for the study area was 4.7315 $\pm 2.3544 \mathrm{~g} \mathrm{~m}^{-2}$.

\section{Size of worms}

The size of the worms varied among sampling points, from $3.9828 \mathrm{~cm}$ (at point 8) to $5.9929 \mathrm{~cm}$ (at point 6) (Table 3).

The average size for the study area was 4.7960 $\pm 0.6219 \mathrm{~cm}$.

Table 1. Number of earthworms (Lumbricus spp.) found in the study area (Estación Experimental of Kallutaca).

\begin{tabular}{|c|c|c|c|c|c|c|c|c|c|c|}
\hline \multirow[b]{2}{*}{ Ring } & \multicolumn{8}{|c|}{ Sampling point $\left(1 \mathrm{~m}^{2}\right)$} & \multirow{2}{*}{$\begin{array}{c}\text { Total } \\
\left(\text { earthworms ring }{ }^{-1}\right)\end{array}$} & \multirow{2}{*}{$\begin{array}{c}\text { Density } \\
\left(\text { earthworms } \mathrm{m}^{-2} \text { ) }\right.\end{array}$} \\
\hline & 1 & 2 & 3 & 4 & 5 & 6 & 7 & 8 & & \\
\hline A 1 & 15 & 21 & 46 & 11 & 13 & 9 & 23 & 6 & 144 & $18.000 \pm 12.68$ \\
\hline A 2 & 5 & 4 & 26 & 13 & 14 & 19 & 34 & 22 & 137 & $17.125 \pm 10.26$ \\
\hline A 3 & 43 & 10 & 31 & 3 & 3 & 14 & 12 & 4 & 120 & $15.000 \pm 14.56$ \\
\hline A 4 & 10 & 10 & 9 & 7 & 14 & 10 & 12 & 3 & 75 & $9.375 \pm 3.29$ \\
\hline A 5 & 17 & 8 & 12 & 14 & 8 & 4 & 3 & 2 & 68 & $8.500 \pm 5.45$ \\
\hline Total individuals $\mathrm{m}^{-2}$ & 90 & 53 & 124 & 48 & 52 & 56 & 84 & 37 & 544 & $13.600 \pm 29.74$ \\
\hline
\end{tabular}


Table 2. Earthworm biomass (Lumbricus spp.) in the study area (Estación Experimental of Kallutaca).

\begin{tabular}{crrrrrrrrrrr}
\hline & \multicolumn{8}{c}{ Average biomass per sampling point } & \multicolumn{1}{c}{ Biomass $\left(\mathrm{g} \mathrm{m}^{-2}\right)$} \\
\cline { 2 - 9 } Ring & 1 & 2 & 3 & 4 & 5 & 6 & 7 & 8 & B \\
\cline { 2 - 9 } A 1 & 2.7984 & 8.6042 & 19.2950 & 4.0080 & 3.9073 & 3.8734 & 8.1119 & 1.0568 & $6.4568 \pm 5.7803$ \\
A 2 & 0.6996 & 0.1425 & 8.0784 & 5.3929 & 3.9521 & 7.5145 & 13.2420 & 5.0502 & $5.5090 \pm 4.2248$ \\
A 3 & 12.8084 & 3.8249 & 11.2213 & 1.8623 & 0.6902 & 3.9521 & 2.6806 & 0.6558 & $4.7119 \pm 4.6948$ \\
A 4 & 4.5308 & 1.8759 & 4.3321 & 3.0839 & 4.3312 & 4.0649 & 4.9125 & 2.2059 & $3.6671 \pm 1.1353$ \\
A 5 & 6.4582 & 1.7771 & 5.1859 & 6.1640 & 3.0306 & 1.5276 & 1.2284 & 1.1321 & $3.3129 \pm 2.2758$ \\
\hline $\begin{array}{c}\text { Average weight } \\
\text { per sampling point }\end{array}$ & 5.4590 & 3.2449 & 9.6225 & 4.1022 & 3.1822 & 4.1865 & 6.0350 & 2.0201 & $4.7315 \pm 2.3544$ \\
\hline
\end{tabular}

Table 3. Average size of earthworms (Lumbricus spp.) in the study area (Estación Experimental of Kallutaca).

\begin{tabular}{|c|c|c|c|c|c|c|c|c|c|}
\hline \multirow[b]{2}{*}{ Ring } & \multicolumn{8}{|c|}{ Average size per sampling point } & \multirow[b]{2}{*}{ Size } \\
\hline & 1 & 2 & 3 & 4 & 5 & 6 & 7 & 8 & \\
\hline A 1 & 2.8533 & 6.0381 & 3.7891 & 5.4454 & 6.2076 & 5.5000 & 5.6695 & 4.9166 & $5.0525 \pm 1.1644$ \\
\hline A 2 & 3.2800 & 1.3750 & 5.8653 & 3.9846 & 4.6500 & 6.2947 & 3.4705 & 3.2227 & $4.0178 \pm 1.5792$ \\
\hline A 3 & 4.3488 & 3.9600 & 4.8677 & 5.1666 & 6.7000 & 4.6500 & 5.5250 & 3.7250 & $4.8678 \pm 0.9505$ \\
\hline A 4 & 6.4900 & 4.6000 & 5.6440 & 4.7571 & 3.6571 & 6.6200 & 4.6166 & 4.5000 & $5.1106 \pm 1.0406$ \\
\hline A 5 & 5.2823 & 5.6250 & 3.8750 & 5.8714 & 4.7500 & 6.9000 & 3.6000 & 3.5500 & $4.9317 \pm 1.2067$ \\
\hline Size & 4.4508 & 4.3196 & 4.8082 & 5.0450 & 5.1929 & 5.9929 & 4.5763 & 3.9828 & $4.7960 \pm 0.6219$ \\
\hline
\end{tabular}

\section{Discussion}

A number of previous studies of worms considered the ecology of the animals in tropical ecosystems. These studies considered the functions filled by endemic species, such as their capacity for natural adaptation if these ecosystems are manipulated by humans (Fragoso, 1993; Lavelle, 1978; Lavelle and Pashanasi, 1989; Nemeth 1981; Senapati, 1980). Studies of worm species on the Bolivian plateau are rare.

In comparative perspective, the density determined by this study for the worms on the High Plateau $\left(13.6 \pm 29.74 \mathrm{~m}^{-2}\right)$ (Table 1) is lower than the values found by Dash and Patra (1977), who reported a range of 64 to 800 individuals $\mathrm{m}^{-2}$ in tropical soils in Orissa (India).

Information on the biology of tropical worms is rare. Only a few species have been studied in the tropics. Environmental conditions, such as humidity, $\mathrm{pH}$, the content of organic matter and agricultural practices are the cause of the remarkable differences in the worm population of the Bolivian plateau found in this study.

A previous study in India (Senapati, 1980) found a density of 17.4 individuals $\mathrm{m}^{-2}$, higher than the value determined by the current study. That study described the close relationship between the reproductive strategies of worms and the ecological categories to which the animals belong. Epigeal worms feed on and live among fallen leaves. They generally survive environmental stress because they produce cocoons. Endogenous worms live and feed in the soil. They resist unfavorable conditions by becoming quiescent, and they enter the reproductive phase when conditions are favorable. Anecids, which live in soil but feed at the surface, use two mechanisms to avoid population mortality. They exhibit diapause, which may be different for adults and juvenile individuals. They also produce cocoons, which appear at the end of the rainy season. Studies of the worms in the soils of the plateau of La Paz are scarce. The 
environmental conditions of the plateau include extreme frosts. During the rainy seasons, the soil floods, and the population is therefore reduced.

The low values of numbers, density and biomass recorded in this study may reflect the effects of a number of factors, such as the depth of the sample collection, the inactivity period of the worms, the sampling schedule, the moisture content and the organic matter present in the soil.

Studies have reported that the destruction of native forests has serious effects on the diversity of earthworms (Bhaduria and Ramkrishnan, 1991). Likewise, the felling and burning of forests in Meghalaya (India) is responsible for reductions of the populations of the original species of forest worms (Darlong and Alfred, 1991).

Previous research conducted in different areas in the rainy season has found higher densities of worms than the density found by this study (Lavelle, 1973; Rozen, 1982; Valle et al., 1997). These studies have generally found a higher abundance, density and taxonomic richness of springtails in the soils with higher worm densities. In addition, they show that the sizes of the springtails and the density of the worms are related. The largest springtails are the most abundant in the zones with the largest numbers of worms. This relationship is explained in terms of higher water and trophic quality and more favorable soil structure (porosity), all of which increase the amount of worm activity. Diverse mesofauna were not observed in the soil in the current study. Environmental conditions, such as temperature and humidity, are hypothesized to be factors influencing the density of the individuals found.

A worm population of 2116 individuals $\mathrm{m}^{-2}$ was found during two study years in the soil of areas devoted to the traditional suka kollus agricultural system in Bolivia. A maximum of 1647 and 481 individuals $\mathrm{m}^{-2}$ were found in soils of the region adjacent to Lake Titicaca during the humid months (Gemio, 1995).
The numbers of worms actually present in the study plot at the Estación Experimental of Kallutaca would have been greater than the numbers measured if worms were present in soil strata deeper than those sampled. In particular, differences in the numbers of individuals per sampling point and ring are evident. The results may reflect the time of day at which the samples were collected because both samples on each sampling day were collected in the early morning.

The variables identified by this study represent a valuable tool for describing the patterns of fluctuation in the worm populations of Andean soils in terms of biological parameters. For example, the population density and biomass of worms was determined at the Estación Experimental of Kallutaca. The information from this preliminary study must be considered a reference for studies on neighboring communities to determine the patterns that relate the population density, biomass, size and sampling depth.

The absence of an evaluation of other variables, such as $\mathrm{pH}$, temperature, humidity and particularly the content of organic matter and other organisms in the soil of the area under study may be a possible explanation of the variation found in the results of this study. The authors of this research agree with the results from the studies previously mentioned. The results of these studies are useful for categorizing the ecological roles of earthworms more precisely.

The biological conditions of agricultural soils on the Bolivian plateau are not considered by technicians, farmers or professionals in the region because of the lack of research relevant to the topic in the Andean region. Such research could yield information that would support agricultural production in the area and might benefit both farmers and researchers in the future.

Numerous factors may be relevant to the variation identified in this research. The following factors are of outstanding interest in this context. 
It is possible that the size of the sampling area or unit was not ideal for the collection of Lumbricus spp. These worms may tend to withdraw towards lower vertical galleries.

The distance between sampling points may have been excessive and prevented the definition of a clear distribution pattern. The worm population and even the sampling points show relatively clear spatial structure. A scale smaller than 10 $\mathrm{m}$ may be preferable. The literature describes variability in the horizontal distribution of worms ranging from $1 \mathrm{~m}$ (Rossi, 1998) to $50 \mathrm{~m}$ (Poier and Richter, 1992).

These considerations and additional factors must be considered for future research that can, for example, map the densities of worm populations in the soils of the Andean zone of Bolivia. Such research would furnish a reference frame that would facilitate agricultural practices with a better economic return.

\section{Acknowledgments}

This research was financed by the authors. The authors thank the Laboratorio of Microbiología Ambiental and Ingeniería Agronómica of Universidad Pública y Autónoma de El Alto (UPEA) for providing the space and materials for this research. Additionally, we thank the person responsible for the Estación Experimental of Kallutaca for allowing us to perform this research.

\section{Resumen}

M.G. Loza-Murguía, R. Acho, A. Arce, R. Huaycho, N. Aruhiza y S. Mamani. 2011. Población de lombrices Lumbricus spp. en el altiplano de La Paz, Bolivia. Cien. Inv. Agr. 38(3): 415-423. La macrofauna es un componente importante dentro de los ecosistemas, pues su participación en la biodegradación de los nutrientes del suelo favoreciendo así la cadena trófica. A lo largo de seis meses, de febrero a julio se evalúo la cantidad de lombrices y su biomasa en $\mathrm{g} \mathrm{m}^{-2}$ en el suelo de la Estación Experimental de Kallutaca ubicada en el altiplano de La Paz, se delimitó una hectárea de suelo en descanso de 10 años aproximadamente que no se ha realizado actividades de laboreo. El área se dividió en cinco anillos, cada anillo presenta ocho puntos de muestreo, cada punto de muestreo se delimitó un metro cuadrado de suelo x $30-35 \mathrm{~cm}$ de profundidad. La densidad y la biomasa de lombrices que se registró en el presente estudio fueron $13,6 \pm 29,74 \mathrm{~m}^{-2}$ y 4,7315 $\pm 2,3544 \mathrm{~g} \mathrm{~m}^{-2}$, respectivamente. La longitud de la lombriz 4,7960 $\pm 0,6219 \mathrm{~cm}$. Posiblemente las características ambientales influyen en el desarrollo de estas en el área estudiada.

Palabras clave: Área de estudio, densidad estacional, lombrices, suelo.

\section{References}

Altieri, M. 1992. Biodiversidad, agroecología y manejo de plagas. Ediciones Cetal. Santiago, Chile. 161 pp.

Beare, M.H., D.C. Coleman, D.A. Crossley, P.F. Hendrix, and E.P.A. Odum. 1995. Hierechical approach to evaluating the significance of soil biodiversity the biogeochemical cycling. Plant and soil. The Hague 170: 5-22.
Bhadauria, T., and P.S. Ramakrishnan. 1991. Population dynamics of earthworms and their activity in forest ecosystem of north east India. Journal of Tropical Ecology 7: 305-318.

Binet, F., and P. Trehen. 1992. Experimental microcosm study of the role of Lumbricus terrestris (Oligochaeta: Lumbricidae) on nitrogen dynamics in cultivated soils. Soil Biol Biochem. 24: 1501-1506.

Bouche, M.B. 1977. Strategies lombriciennes. In: Lohm, U. and Persson, T. (eds.) Soil Organisms 
as Components of Ecosystems. p. 122-132. Biology Bulletin, Stockholm. Sweden.

Brown, G.G., C. Feller, E. Blanchart, P. Deleporte, and S.S. Cheryanskii. 2003. With Darwin, earthworms turn intelligent and become human friends. Pedobiologia 47: 924-933.

Butcher, J.W., and R.J. Snider. 1971. Bioecology of edaphic Collembola and Acarina. Annual Review of Entomology, Palo Alto 16: 249-288.

Camacho, M. 2001. La gestión del espacio y las prácticas de manejo del suelo en la región altiplánica de Bolivia: el caso de la comunidad de Patarani en la Provincia Aroma. Tesis de Magister Scientiae en Ecología y Conservación, Instituto de Ecología, Universidad Mayor de San Andrés, La Paz, Bolivia. 82 pp.

Daniel, O., and J.M. Anderson. 1992. Microbial biomass and activity in contrasting soil materials after passage through the gut of the earthworn Lumbricus rubellus Hoffmeister. Soil Biol Biochem. 24: 465-470.

Darlong, V.T., and J.R.B. Alfred. 1991. Effect of shifting cultivation (jhum) on soil fauna with particular reference to earthworms in north east India. In: Veeresh, G.K., Rajgopaland, D. and Viraktmath, C.A. (eds.). Advances in management and conservation of soil fauna. Oxford and IBH, New Delhi. p. 299-308.

Dash, M.C., and U.C. Patra. 1977. Density, biomass and energy budget of a tropical earthworm population from a grassland site in Orissa, India. Rev. Ecol. Biol. Sol. 14: 461-471.

De Vleeschauwer, D., and R. Lal. 1981. Properties of worn casts under secondary tropical forest regrowth. Soil Sci. 132: 171-181.

Dominguez, J., J.P. Bohlen, and R.W. Parmelee. 2004. Earthworms increase nitrogen leaching to greater soil depths in row crop. agroecosystems. Ecosystems 7:672-685.

Edwards, C.A., and P.J. Bohlen. 1996. Biology and Ecology of Earthworms. Chapman \& Hall, Londres. $426 \mathrm{pp}$.

Fragoso, C. 1985. Ecología general de las lombrices terrestres (Oligochaeta: Annelida) de la región Boca del Chajul. Selva Lacandona (Chiapas, México). Tesis de Magister. Universidad Nacional Autónoma de México, México. 56 pp.

Fragoso, C. 1993. Les peuplements de vers de terre dans L'est et sud-est du Mexique. Tesis Doctoral. Université Paris 6. 228 pp.

Gemio, E.T. 1995. Estudio de la actividad y abundancia de las lombrices. (Annelida: Oligochaeta) en la capa arable de los Sucakollus. Tesis. Universidad Mayor de San Andrés. La Paz, Bolivia. 126 pp.

Haynes, R.J., and P.M. Fraser. 1998. A comparison of aggregate stability and biological activity in earthworm casts and uningested soil as affected by amendment with wheat or Lucerne straw. Eur. J. Soil Sci. 49: 629-636.

Jiménez, J.J., A.G. Moreno, P. Lavelle, and T. Decaens. 1998. Population dynamics and adaptative strategies of Martiodrilus carimaguensis (Oligochaeta, Glossoscolecidae), a native species from the well-drained savannas of Colombia. Appl. Soil Ecol. 9:153-160.

Lavelle, P., and A.V. Spain. 2001. Soil Ecology. Kluwer Academic Publishers. Dordrecht Boston, London. 654 pp.

Lavelle, P. 2000. Ecological challenges for soil science. Soil Science 165: 73-86.

Lavelle, P., C. Lattaud, D. Trigo, and D. Barois. 1995. I. Mutualism and biodiversity in soils. Plant and Soil, The Hague 170: 23-33.

Lavelle, P., and B. Pashanasi. 1989. Soil mesofauna and land management in Peruvian Amazonia (Yurimaguas, Loreto). Pedobiologia 33:283-291.

Lavelle, P. 1978. Les vers de terre de la savane de Lamto (Cote d'Ivoire):peuplements, populations et fonctions dans L'ecosysteme. Paris 6, Publ. Lab. Zool. ENS. 12. 301 pp.

Lavelle, P. 1973. Peuplement et production des vers de terre des Savanes de Lamto. Annals of the University Abidjan, Ser E. 6: 79-98.

Lee, K.E. 1985. Earthworms. Their Ecology and Relationships with Soils and Land Use. Academic Press. Sydney, Australia. 411 pp.

Lee, K.E., and C.E. Pankhurst. 1992. Soil organisms and sustainable productivity. Aust. J. Soil Res. 30: 855-892.

Martin, S., and P. Lavelle. 1992. A simulation model of the vertical movements of an earthworm population (Millsonia anomala, Omodeo, Megascolecidae) in an African savanna (Lamto, Ivory Coast). Soil Biol. Biochem. 24:1419-1424.

Nemeth, A., and R. Herrera. 1982. Earthworm population in Venezuela rain forest. Pedobiologia 23:437-443.

Nemeth, A. 1981. Estudio ecológico preliminar de las lombrices de tierra (Oligochaeta) en ecosistemas de bosque húmedo tropical en San Carlos de Río Negro, Territorio Federal Amazonas. Tesis Magister. Universidad Central de Venezuela. Caracas, Venezuela. 92 pp. 
Norgrove, L., and S. Hauser. 2000. Production and nutrient content of earthworm casts in tropical agrisilvicultural system. Soil Biol. Biochem. 32: 1651-1660.

Parthasarathi, K., and L.S. Ranganathan. 1999. Longevity of microbial and enzime activity and their influence on NPK content in pressmud vermicasts. Eur. J. Soil Biol. 36: 107-113.

Poier, K.R., and J. Richter. 1992. Spatial distribution on earthworm and soil properties in an arable loess soil. Soil Biol. Biochem. 24:1601-1608.

Reddy, M.V., and M. Pasha. 1993. Influence of rainfall, temperature and some soil physico-chemical variables on season population structure and vertical distribution of earthworms in two semi-arid tropical grassland soils. Int. J. Biometeor. 37:1926.

Rossi, J.P. 1998. Röle fonctionnel de la distribution spatiale des vers de terre d'une savane remide de Cöte d'Ivoire. Tesis. Université Pierre et Marie Curie, París 6. 192 pp.

Rozen, A. 1982. The annual cycle in populations of earthworms (Lumbricidae, Oligochaeta) in three types of oak-hornbeam of the Niepolomicka Forest. I. Species composition, dominance, frequency and associations. Pedobiologia 23: 199-208.

Seasted, T.R. 1984. The role of microarthropods in decomposition and mineralization processes.
Annual Review of Entomology, Palo Alto 29: 25-46.

Senapati, B.K. 1980. Aspects of ecophysiological studies on tropical earthworms: distribution, population dynamics, production, energetics and their role in the descoposition process. Tesis Doctoral. Sambalpur University. India. 154 pp.

Shuster, W.D., S. Subler, and E.L. McCoy. 2000. Foraging by deep-burrowing earthworm degrades surface soil structure of a fluventic Hapludollin in Ohio. Soil Till. Res. 54: 179-189.

Tiunov, A.V., and S. Scheu. 2000. Microbial biomass, biovolume and respiration in Lumbricus terrestris L. Cast material of different age. Soil Biol. Biochem. 32: 265-275.

Valle, J.V., R.P. Moro, H.M Gravin, D. Trigo, and D.D.J. Cosin. 1997. Annual dynamics of the earthworm Hormogaster elisae (Oligochaeta, Hormogastridae) in central Spain. Soil Biology and Biochemistry 29: 309-312.

Wallwork, J.A. 1970. Ecology of soil animals. London: McGraw-Hill. 283 pp.

Willoughby, G.L., and E.J. Kladivko. 2002. Water infiltration rates following reintroduction of Lumbricus terrestris into no-till fields. J. Soil Water Conser. 57: 82-88.

Witkamp, B. 1971. Soils as components of ecosystems. Ecology Systematics 2: 85-110. 
